
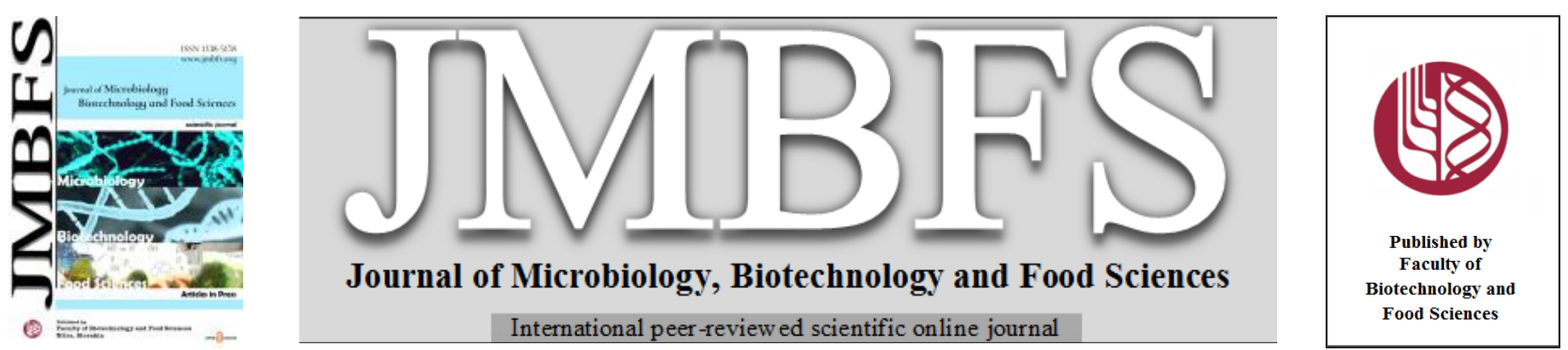

\title{
ISOLATION AND CHARACTERISATION OF A NEW ALKALI-HALOTOLERANT BACILLUS AQUIMARIS STRAIN LGMT10, PRODUCING EXTRACELLULAR HYDROLASES, FROM THE EFFLUENTS OF A THERMAL POWER PLANT, IN ALGERIA
}

\author{
Abdelkrim Chaida ${ }^{1}$, Farid Bensalah ${ }^{1}$, Amel Guermouche M'rassi ${ }^{1}$
}

Address(es):

${ }^{l}$ Laboratory of Microbial Genetics (LGM), Department of Biology, Faculty of Natural and Life Sciences, University Oran 1, 31000 Oran, Algeria.

*Corresponding author: chaida.abdelkrim@gmail.com

https://doi.org/10.15414/jmbfs.3460

\section{ARTICLE INFO}

Received 16. 7. 2020

Revised 26. 6. 2021

Accepted 1.7. 2021

Published 1. 12. 2021

Regular article OPEN $\partial_{\text {AcCESS }}$

\begin{abstract}
Modern biotechnology takes into account cost, performance, and respect for the environment to set up an industrial process. In this sense, the study's goal is to highlight the presence of indigenous microbial microflora in the Terga thermal power plant effluents, which are capable of secreting extracellular hydrolases. Four different extracellular hydrolases classes, which are most of the time used in bioindustry, namely protease, amylase, lipase, and cellulase, were investigated in agar plate assay, to select microorganisms with an interesting enzymatic potential adapted to this type of environment. Consequently, the results have shown that among twelve isolated bacterial strains, three strains were screened based on their enzymatic potential, and were later identified by $16 S$ rRNA gene sequencing, i.e. showing that the strains belong to the genus Pseudomonas aeruginosa, and Bacillus wiedmannii with a similarity percentage of $99.33 \%$ and $100 \%$, respectively, with their corresponding type of strains. Among them, the strain LGMT10 that belongs to the Bacillus genus, and is closely related to Bacillus aquimaris, showed a $16 \mathrm{~S}$ rRNA sequence similarity with the type of strain of $99.23 \%$. This strain presents adequate characteristics to resist the harsh conditions of $\mathrm{pH}$ and $\mathrm{NaCl}$. It could grow against wide ranges of $\mathrm{NaCl}$ concentrations between $0-12 \%(\mathrm{w} / \mathrm{v}), \mathrm{pH} 5.5-12$, and was able to produce extracellular hydrolases (i.e., protease, amylase, and cellulase) against pH ranges of 6.812 and $\mathrm{NaCl}$ concentrations between $0-12 \%(\mathrm{w} / \mathrm{v})$ at $30^{\circ} \mathrm{C}$. This strain's intriguing enzymatic potential, as well as its $\mathrm{pH}$ and salinity tolerance, make it a promising candidate for various biotechnological applications in detergent, leather, textile, and food processing industries.
\end{abstract}

Keywords: amylase; cellulase; protease; lipase; alkali-halotolerant; Bacillus aquimaris

\section{INTRODUCTION}

The search for new eco-friendly means potentially involved in various industria processes has directed the scientific community to microbial enzymes (Ardakani et al., 2012). In recent years, research dealing with enzymes of extremophilic microorganisms has found great interest (Shukla, 2019). However, many microbes such as bacteria, actinomycetes, fungi, and yeast extracellularly or intracellularly produce a group of versatile and attractive enzymes with a wide variety of structures and commercial applications. Many microbial enzymes, such as amylases, proteases, pectinases, lipases, xylanases, cellulases, and laccases are extracellularly produced (Fiedurek and Gromada, 2000; Venkateshwaran $\boldsymbol{e t}$ al., 1999).

The microbial enzymes have gained recognition globally for their widespread uses in various industrial sectors, e.g., food, agriculture, chemicals, medicine, and energy. Enzyme mediated processes are rapidly gaining interest because of reduced processing time, intake of low energy input, cost-effective, non-toxic and ecofriendly characteristics (Li et al., 2012; Choi et al., 2015). In addition, the microbial enzymes have been given more attention due to their active and stable nature compared to enzymes extracted from plants and animals (Anbu et al., 2013; Gopinath et al., 2013). Most microorganisms are unable to grow and produce enzymes under harsh environments that cause toxicity. However, some microorganisms have undergone various adaptations enabling them to grow and produce enzymes under harsh conditions (Sardessai and Bhosle, 2004; Anbu, 2016). Recently, several studies have been initiated to isolate new bacterial and fungal strains from harsh environments such as extreme $\mathrm{pH}$, temperature, salinity, heavy metal, and organic solvent, in order to the produce different enzymes having the properties to yield higher (Anbu, 2016; Gopinath et al., 2005).

Halotolerant bacteria form a versatile group adapted to life at the lower range of salinities, with the possibility of rapid adjustment to changes in the external salt concentration (Litchfield, 2002). This property of halotolerant bacteria makes them better candidates for bio-prospecting than their halophilic counterparts Enzymes of the halotolerant bacteria find a very interesting field of application However, halotolerant proteases are hydrolytic enzymes, which are mostly used in industries. For example, detergent industries add halotolerant proteases to their laundry detergent formulations in order to hydrolase proteinaceous stains (Anwar and Saleemuddin, 1998). The tannery industry uses halotolerant proteases to assist in de-hairing of animal hides (Abd Samad et al., 2017). Moreover, the identification of novel bacterial cellulases remains a currently explored route to the development of modern sustainable bio-industries for biofuel generation (Novy et al., 2015). Thermo-alkali-stable cellulases isolated from extremophilic Bacillus strains have shown their potential within conditions that are appropriate for bioconversion processes (Souii et al., 2020).

Marine microorganisms have been attracting more attention as a resource for new enzymes. The complexity of the marine environment involving high salinity, high pressure, low temperature, and special lighting conditions may contribute to the significant differences between the enzymes from marine microorganisms and homologous enzymes from terrestrial microorganisms (Zhang and Kim, 2010) Besides that, new approaches such as metagenomics need to be performed to identify new groups of bacteria that remain unexplored in the seas and oceans (Sharma et al., 2019).

In this context, the current research highlighted the promising potential of a newly isolated marine source bacterium; Bacillus aquimaris strain LGMT10, isolated from the effluents of the Terga thermal power plant, in western Algeria, after $16 \mathrm{~S}$ rDNA sequencing. This bacterial strain can produce three extracellular enzymes (i.e., amylase, protease, and cellulase). It is a preliminary screening study that uses a qualitative method of producing extracellular hydrolases by indigenous microorganisms isolated from a new underutilized site in Algeria. 


\section{MATERIALS AND METHODS}

Sampling

The effluents of a well-known thermal power plant near the sea, in the Terga region of Ain Temouchent (GPS Coordinates: 35 $27^{\circ} 43.2^{\prime \prime} \mathrm{N} 1^{\circ} 13^{\prime} 40.5^{\prime \prime} \mathrm{W}$ ), were the subject of this study. Seawater is the main source for the operation of the thermal power plant, which consequently generates effluents. The samples were collected at $60 \mathrm{~m}$ before the discharge area into the sea (Figure 1), in sterile flasks, and then transferred directly to the laboratory and placed in a cold room $\left(4{ }^{\circ} \mathrm{C}\right)$ for further analysis. The $\mathrm{pH}$ of the effluents at the time of collection was recorded to be 7.57.8 , the temperature $25^{\circ} \mathrm{C}$, and the concentration of rejected chlorine $0.25 \mathrm{ppm}$.
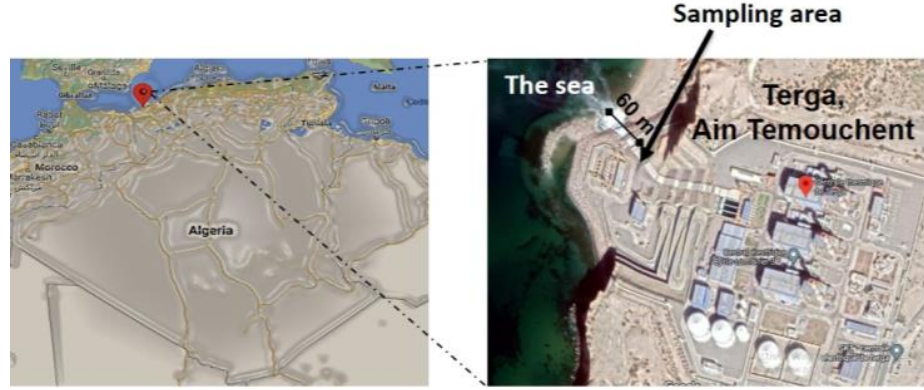

Figure 1 Sampling area of the Terga thermal power plant

\section{Enrichment and isolation of microorganisms}

One millilitre of the sample was transferred aseptically to $9 \mathrm{ml}$ of nutrient broth (NB). After incubation at $30{ }^{\circ} \mathrm{C}$ for $1-2$ days, decimal dilutions series were performed according to the method described by Nandhini and Josephine (2013) For isolation, volumes of the bacterial cultures were diluted with a $0.85 \%(\mathrm{w} / \mathrm{v})$ sodium chloride pre-sterilized. Decimal dilutions of $10^{-1}$ to $10^{-7}$ were made and 1 $\mathrm{ml}$ of the dilutions $\left(10^{-5}, 10^{-6}\right.$, and $\left.10^{-7}\right)$ was plated onto NB agar plates containing a nutrient agar composed of: Peptone (10g), yeast extract (5g), $\mathrm{NaCl}(5 \mathrm{~g})$, Agar $(15 \mathrm{~g})$, and distilled water (1litre). The dishes were incubated at $30^{\circ} \mathrm{C}$ under aerobic conditions for 2 days. After incubation, colonies of different morphologies were isolated and purified. The pure isolates were stored at $\left(-20^{\circ} \mathrm{C}\right)$ on a NB medium supplemented with glycerol $20 \%$ (v/v) for further studies.

\section{Study of enzymatic activities of isolates}

This paper is interested in the study of four hydrolase classes that have a wide range of biotechnology applications:

\section{Protease activity}

In order to select the proteolytic microorganisms, a milk agar medium composed of: Yeast extract $(3 \mathrm{~g})$, agar $(15 \mathrm{~g})$, and distilled water (1 litre), was used. This mixture was adjusted to $\mathrm{pH} 7.8$ and autoclaved at $121^{\circ} \mathrm{C}$ for $15 \mathrm{~min}$. Then, $100 \mathrm{ml}$ of skimmed milk (manufactured by Soummam, Algeria) was added sterilely after cooling the mixture. Microorganisms that hydrolyze milk casein show lightening halos around colonies (Ardakani et al., 2012).

\section{Amylase activity}

The amylolytic activity of pure isolates was demonstrated in a starch-based agar medium composed of: peptone $(10 \mathrm{~g}), \mathrm{NaCl}(5 \mathrm{~g})$, yeast extract $(5 \mathrm{~g})$, starch $(1 \%$, $\mathrm{w} / \mathrm{v})$, agar $(15 \mathrm{~g})$, and distilled water (1 litre). $\mathrm{pH} 7.8$. Microorganisms, which hydrolyze the starch, show clear halos around the colonies after the addition of a Lugol solution for $15 \mathrm{~min}$ followed by two rinses with distilled water (Ardakani et al., 2012).

\section{Lipase activity}

This activity was performed in tween 80 agar medium composed of $(\mathrm{g} / \mathrm{l})$ : peptone (10g), $\mathrm{NaCl}(5 \mathrm{~g}), \mathrm{CaCl}_{2}(0.1 \mathrm{~g})$, agar $(15 \mathrm{~g})$, tween $80(1 \%$, v/v), distilled water (1 litre). $\mathrm{pH}$ 7.8. After incubation for 3-4 days, microorganisms that hydrolyze tween 80 show opaque halos around the colonies (Hasan et al., 2009).

\section{Cellulase activity}

This medium was composed of two media as described by Koraichi et al. (2015) A minimum medium M9 and a carboxymethylcellulose (CMC) medium. The M9 medium consists of $\mathrm{Na}_{2} \mathrm{HPO}_{4}(6 \mathrm{~g}), \mathrm{KH}_{2} \mathrm{PO}_{4}(3 \mathrm{~g}), \mathrm{NH}_{4} \mathrm{Cl}(1 \mathrm{~g}), \mathrm{NaCl}(0.5 \mathrm{~g})$, and distilled water (1 litre). The medium was autoclaved for $15 \mathrm{~min}$ at $121^{\circ} \mathrm{C}$. Then, 1 $\mathrm{ml}$ of a 0.1 molar solution of $\mathrm{CaCl}_{2}$ and $1 \mathrm{ml}$ of a 1 molar solution of $\mathrm{MgSO}_{4}$ are added. The CMC medium was composed of CMC (10g), yeast extract (5 g), glycerol $(50 \%, \mathrm{v} / \mathrm{v})(2 \mathrm{ml})$, agar $(20 \mathrm{~g})$ and the M9 buffer (quantity per litre). This

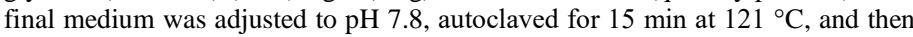
poured into Petri dishes. After incubation for 2 days at $30^{\circ} \mathrm{C}$, the cellulase activity was demonstrated by adding a solution of lugol for $15 \mathrm{~min}$ followed by three rinses with a molar solution of $\mathrm{NaCl}$. Microorganisms that have cellulase activity show yellowish rings around the colonies.

\section{Characterization of bacteria}

The isolated strains were identified based on phenotypic and biochemical characteristics such as sugars fermentation (i.e., glucose, lactose, saccharose, and mannitol), citrate utilization test, mobility test and others, using the Bergey's Manual of Determinative Bacteriology as a guide, and on molecular characteristics by the sequencing of $16 \mathrm{~S}$ rRNA gene after extraction and Polymerase Chain Reaction (PCR) amplification, using the boiling method. This later consisted of bringing a pure colony to the boil for $10 \mathrm{~min}$, and centrifuged at $15,000 \mathrm{rpm}$ for 5 min at $4{ }^{\circ} \mathrm{C}$ (Dutka-Malen et al., 1995). The amplification of the $16 S$ rRNA gene was carried out in a TC3000 Thermocycler using the following PCR program: Predenaturation $95{ }^{\circ} \mathrm{C}$ for $15 \mathrm{~min}$, denaturation $94{ }^{\circ} \mathrm{C}$ for $1 \mathrm{~min}$, hybridization 60 ${ }^{\circ} \mathrm{C}$ for $1 \mathrm{~min}$, and elongation $72{ }^{\circ} \mathrm{C}$ for $1.5 \mathrm{~min}$, folowwed by final elongation 72 ${ }^{\circ} \mathrm{C}$ for $10 \mathrm{~min}$. The reaction mixture was composed of $2.5 \mu \mathrm{l}$ of the buffer solution, $2 \mu \mathrm{l}$ DNTP, $0.5 \mu \mathrm{l}$ universal forward primer (27F: 5' AGAGTTTGATCCTGGCTCAG-3'), $0.5 \mu$ universal reverse primer (1492R: 5' TACGGGTACCTTGTTACGACTT-3') (Sato et al., 2003), $0.25 \mu$ l Taq polymerase, $5 \mu \mathrm{l}$ of the bacterial cells, and $14.25 \mu \mathrm{l}$ of distilled water. The PCR products were visualized after migration in an electrophoresis gel composed of 1.2 $\mathrm{g}$ of agarose per $100 \mathrm{ml}$ of Tris-Borate-EDTA (TBE) buffer containing ethidium bromide. After the sequencing, according to the Sanger method, the nucleotide sequences of $16 \mathrm{~S}$ rRNA gene were aligned with other sequences via BLAST (Basic Local Alignment Search Tool) using NCBI (National Center for Biotechnology Information) database. The construction of the phylogenetic tree was performed using MEGA 7: Molecular Evolutionary Genetics Analysis (Kumar et al., 2016) The $16 \mathrm{~S}$ rDNA nucleotide sequences of strains LGMT10, LGMT12, and LGMT8 have been deposited in GenBank/ENA/EMBL databases under the accession numbers : MT337422, MT337423, and MT344187, respectively.

\section{Growth curves}

Two growth curves of bacterial culture of the strain LGMT10 were plotted as a function of time at different $\mathrm{pH}(\mathrm{pH} \mathrm{5.5,6.5,8,10,} \mathrm{and} \mathrm{12)} \mathrm{and} \mathrm{concentrations} \mathrm{of}$ $\mathrm{NaCl}(0,4,8,12$, and $16 \%, w / v)$ to study respectively the alkali tolerance and halotolerance in NB medium composed of $(\mathrm{g} / \mathrm{l})$ : casein peptone $(10 \mathrm{~g})$, yeast extract $(5 \mathrm{~g}), \mathrm{NaCl}$ (at the studied concentrations) and distilled water (1 litre). The bacterial cultures were taken aseptically every $12 \mathrm{~h}$ and the optical density (OD) was measured at a wavelength of $600 \mathrm{~nm}$ (Shivanand and Jayaraman, 2009). Results are expressed as the mean of two replicates tests \pm standard deviation. Principa component analysis (PCA) was used to highlight the strain LGMT10's optimal pH and $\mathrm{NaCl}$ growth parameters.

\section{Effect of $\mathrm{pH}$ and concentration of $\mathrm{NaCl}$ on the enzymatic activities}

In order to investigate the influence of $\mathrm{pH}$ and $\mathrm{NaCl}$ concentrations on the production of extracellular enzymes (protease, amylase, and cellulase) by the strain LGMT10, different enzymatic assays were carried out in agar plate assay, with different $\mathrm{pH}(\mathrm{pH} 6.8,8.5,10$, and 12), and different concentrations of $\mathrm{NaCl}(0,4$, 8 , and $12 \%, \mathrm{w} / \mathrm{v}$ ) at a constant temperature of $30^{\circ} \mathrm{C}$. After incubation for $48 \mathrm{~h}$, the secretion of enzymes was manifested by the formation of halos around the colonies. Another experiment on enzymatic activities was conducted by combining the optimal $\mathrm{pH}$ and $\mathrm{NaCl}$ growth parameters.

\section{Statistical analyses}

Principal component analysis (PCA) was used to compare the effects of different $\mathrm{NaCl}$ concentrations and $\mathrm{pH}$ ranges for the LGMT10 strain growth, using the XLSTAT ${ }^{\circledR}$ software (trial version). The LGMT10 strain's growth at different $\mathrm{NaCl}$ concentrations and $\mathrm{pH}$ ranges was performed at two replicates tests. Means and standard deviations were calculated using GraphPad Prism 9 (Trial version).

\section{RESULTS}

Isolation, screening, and characterization of bacteria

The isolation of microorganisms from the effluents, after enrichment in NB medium, showed a bacterial diversity with interesting enzymatic potential as shown in Tab 1. Among twelve bacterial isolates, three isolates designated LGMT10, LGMT12, and LGMT8 were screened based on their interesting enzymatic potential (Tab 1). The strain LGMT10 was selected for its enzymatic potential amylase, cellulase, and protease, by showing broad halos around the 
colonies (Figure 2). It is short rod, Gram-positive, catalase-positive, oxidasenegative, which forms pale orange-yellow colonies on the surface of a nutrient agar medium after $24 \mathrm{~h}$ of incubation at $30{ }^{\circ} \mathrm{C}$ (Figure 3 ). It grows against wide ranges of $\mathrm{NaCl}$ concentrations between $0-12 \%(\mathrm{w} / \mathrm{v})$ and $\mathrm{pH} 5.5-12$ at $30{ }^{\circ} \mathrm{C}$. Based on phenotypic and biochemical analyzes, and according to Bergey's Manual of Determinative Bacteriology; the strain was tentatively classified as Bacillus sp (Tab 2). Phylogenetic analysis based on $16 S$ rRNA gene sequencing showed $99.23 \%$ homology with the type of strain Bacillus aquimaris strain DSM $16205^{\mathrm{T}}$
(GenBank Accesion no.: AF483625) (Figure 4). For the strains LGMT12 and LGMT8, the percentage of similarity of the $16 \mathrm{~S}$ rRNA gene with their corresponding type of strains is $99.93 \%$ and $100 \%$, respectively, for Pseudomonas aeruginosa strain DSM 50071 ${ }^{\mathrm{T}}$ (GenBank Accesion no.: HE978271) and Bacillus wiedmannii strain DSM 102050 ${ }^{\mathrm{T}}$ (GenBank Accesion no.: KU198626). ) (Figure 4).

\begin{tabular}{|c|c|c|c|c|c|c|c|}
\hline Bacterial code & $\begin{array}{l}\text { Microscopic } \\
\text { observation }\end{array}$ & $\begin{array}{l}\text { Gram's } \\
\text { staining }\end{array}$ & Catalase test & $\begin{array}{c}\text { Protease } \\
\text { activity }\end{array}$ & $\begin{array}{l}\text { Amylase } \\
\text { activity }\end{array}$ & $\begin{array}{c}\text { Lipase } \\
\text { activity }\end{array}$ & $\begin{array}{c}\text { Cellulase } \\
\text { activity }\end{array}$ \\
\hline LGMT1 & Cocci & - & - & - & - & - & + \\
\hline LGMT2 & Rods & + & + & - & + & - & + \\
\hline LGMT3 & Rods & - & + & ++ & - & +++ & + \\
\hline LGMT4 & Cocci & - & + & - & + & ++ & - \\
\hline LGMT5 & Cocci & - & + & - & - & + & + \\
\hline LGMT6 & Cocci & - & + & ++ & + & - & - \\
\hline LGMT7 & Cocci & - & - & ++ & + & - & - \\
\hline LGMT8 & Rods & + & + & +++ & - & ++ & - \\
\hline LGMT9 & Rods & - & + & ++ & + & + & + \\
\hline LGMT10 & Rods & + & + & +++ & ++ & - & ++ \\
\hline LGMT11 & Rods & - & + & ++ & + & + & - \\
\hline LGMT12 & Rods & - & + & ++ & - & ++ & + \\
\hline
\end{tabular}

Legend: (-) - no halos, (++) - medium diameter halos, (+++) - large diameter halos

Table 2 Biochemical characteristics of the strain LGMT10

\begin{tabular}{ll}
\hline Characteristics & Results \\
\hline Gram's staining & + \\
Endospore staining & Central spores \\
$\mathrm{NaCl}$ growth range $(\%, \mathrm{w} / \mathrm{v})$ & $0-12$ \\
$\mathrm{pH}$ growth range & $5.5-12$ \\
Sugars fermentation : & \\
1.Glucose & - \\
2.Lactose & + \\
3.Saccharose & + \\
4.Manitol & + \\
Citrate utilization test & - \\
Mobility & + \\
Catalase test & + \\
Oxidase test & - \\
Urease test & - \\
Indole production & - \\
Hydrolysis of tween 80 & - \\
Hydrolysis of olive oil & - \\
Hydrolysis of skimmed milk & + \\
Hydrolysis of starch & + \\
Hydrolysis of cellulose & + \\
\hline
\end{tabular}

Legend: (+) - positive result, (-) - Negative result

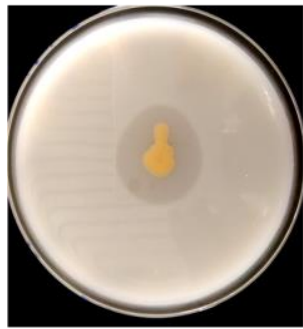

Figure 2 Enzymatic activities of the strain LGMT10 after 2 days of incubation at $30{ }^{\circ} \mathrm{C}$, (a): Protease activity indicates hydrolysis of casein, (b): Cellulase activity indicates hydrolysis of cellulose, (c): Amylase activity indicates hydrolysis of starch b
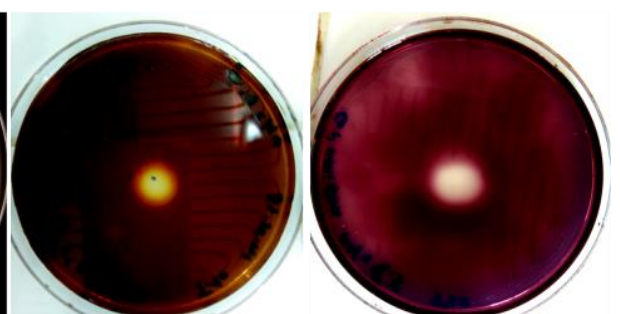

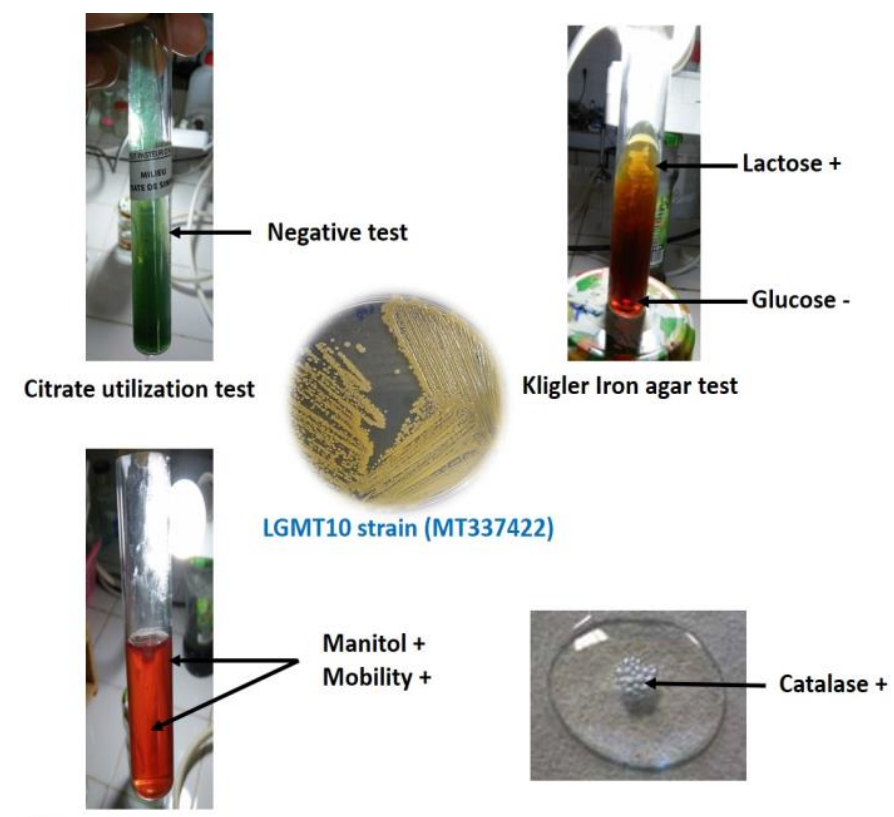

Manitol mobility test

Figure 3 Some Phenotypic and biochemical characteristics of the strain LGMT10 


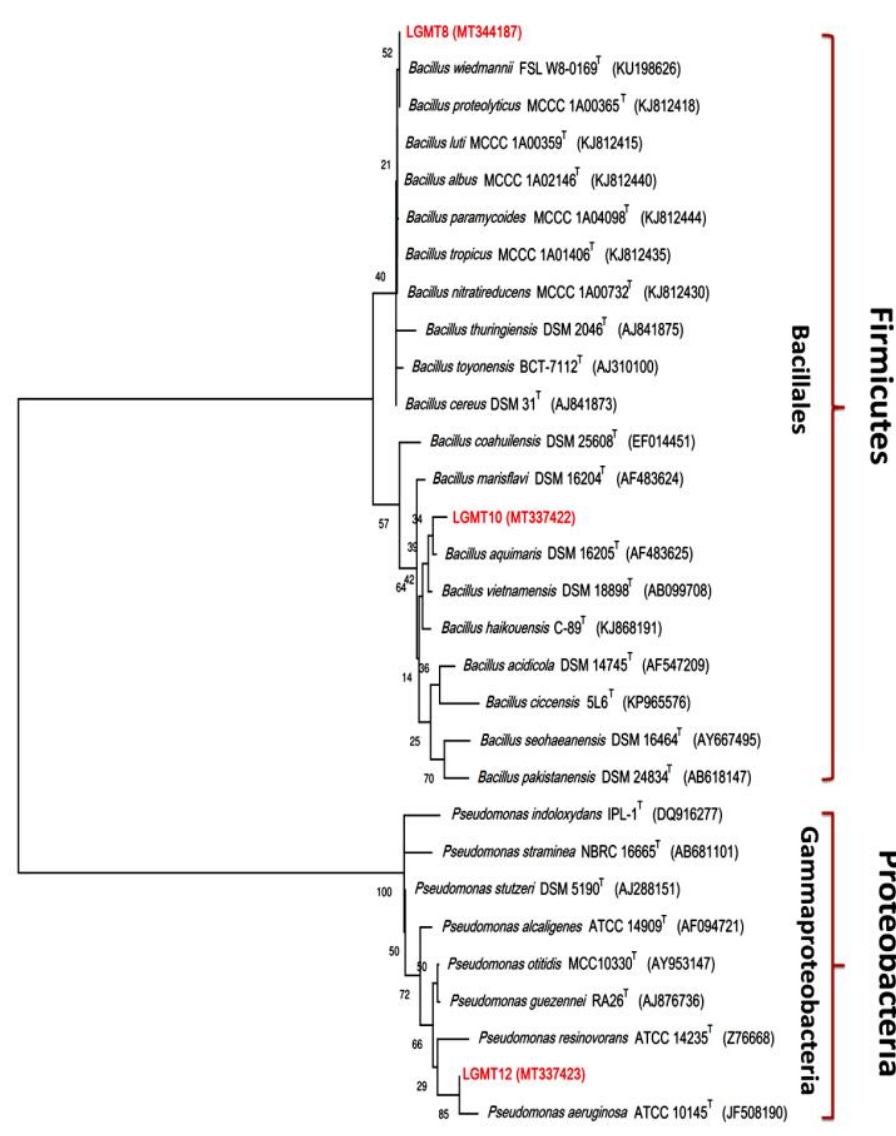

4 Phylogenetic tree by Maximum Likelihood method based on $16 S$ rRNA sequences of the strains LGMT8, LGMT12, LGMT10 and related species of BLASTn database. The trees were generated with 1000 repetitions and the percentages $(\%)$ at the node represent the probability values of the robustness of the similarity. Bar $=0.1$ nucleotide substitution per site

\section{Growth curve}

Monitoring the growth of the strain LGMT10 over time has shown its capacity to grow on different concentrations of $\mathrm{NaCl}(0-12 \%$, w/v), with optimal growth observed in $\mathrm{NB}$ medium at a concentration of $4 \%(\mathrm{w} / \mathrm{v}) \mathrm{NaCl}$, i.e., where the best rate growth was noted. This allowed the strain to be classified as moderately halophilic bacterium, indicating that it originated from the sea. (Shivanand and Jayaraman 2009) (Figure 5a). On the other hand, monitoring the growth against various $\mathrm{pH}$ ranges has shown that the LGMT10 strain can resist a $\mathrm{pH}$ range of 5.512 , with an optimum growth $\mathrm{pH}$ observed at $\mathrm{pH} 8$, i.e., where the best growth rate was recorded. As a result, the strain could be classified as an alkali-tolerant bacterium (Figure 5b). The effect of $\mathrm{NaCl}$ and $\mathrm{pH}$ on the LGMT10 strain's growth was demonstrated using principal component analysis. Accordingly, the best conditions for bacterial growth have been identified (i.e., $4 \% \mathrm{NaCl}$ and $\mathrm{pH} 8$ ) (Figure 6) a

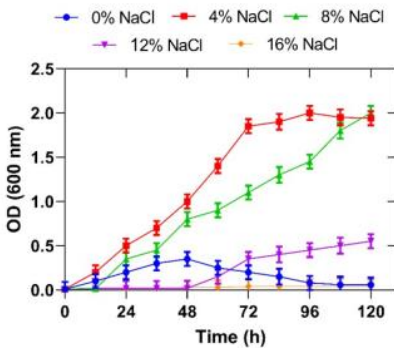

\section{b}

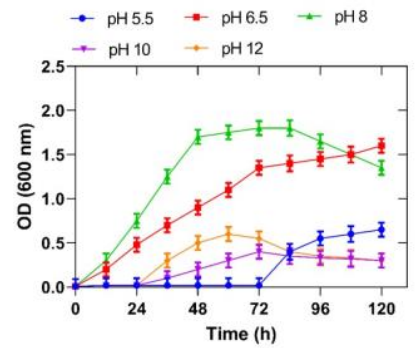

Figure 5 Growth monitoring (OD $600 \mathrm{~nm}$ ) each $12 \mathrm{~h}$ at $0 \% \mathrm{NaCl}(\bullet), 4 \% \mathrm{NaCl}$ $(\boldsymbol{\bullet}), 8 \% \mathrm{NaCl}(\boldsymbol{\Delta}), 12 \% \mathrm{NaCl}(\boldsymbol{\nabla}), 16 \% \mathrm{NaCl}(\bullet)(\mathrm{a})$; and in the $\mathrm{pH} 5.5(\bullet), \mathrm{pH}$ $6.5(\boldsymbol{\bullet}), \mathrm{pH} 8(\boldsymbol{\Delta}), \mathrm{pH} 10(\boldsymbol{\nabla}), \mathrm{pH} 12(\bullet)(\mathrm{b})$, of the strain LGMT10 on NB medium at $30{ }^{\circ} \mathrm{C}$

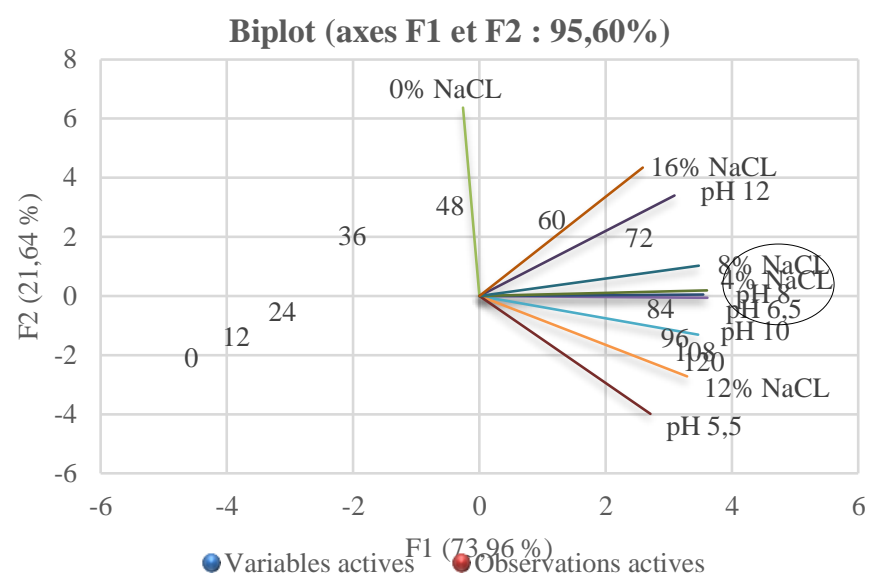

Figure 6: Principal component analysis of the turbidimetry measurements recorded for the LGMT10 strain at different salt concentrations and $\mathrm{pH}$ ranges, after 10 time of incubation. Projection of the variables on the factorial plane. The variables are the different salt concentrations ( $0 \%$ to $12 \%)$ and $\mathrm{pH}$ ranges $(\mathrm{pH} 5.5$ to $\mathrm{pH} 12$ ). Projection of samples corresponding to the 10 times of incubation

Effect of $\mathrm{pH}$ and $\mathrm{NaCl}$ concentration on the enzymatic activities

The production of the enzymes amylase, protease and cellulase was highlighted by the formation of halos around the colonies against wide ranges of $\mathrm{pH}$ 6.8-12 (with the exception of the amylase activity against $\mathrm{pH} 8.5-12$ ), and $\mathrm{NaCl}$ concentrations between $0-12 \%(\mathrm{w} / \mathrm{v})$ (with the exception of the cellulase activity against $4-12 \%$ $(\mathrm{w} / \mathrm{v})$ of $\mathrm{NaCl})$ at $30^{\circ} \mathrm{C}$ for 2-3 days of incubation (Tab 3).

Table 3 Effect of $\mathrm{pH}$ and $\mathrm{NaCl}$ concentration on the enzymatic activities of the strain LGMT10

\begin{tabular}{|c|c|c|c|c|c|c|c|c|c|c|c|c|c|c|}
\hline \multicolumn{5}{|c|}{ Protease activity } & \multicolumn{5}{|c|}{ Amylase activity } & \multicolumn{5}{|c|}{ Cellulase activity } \\
\hline $\begin{array}{l}\mathrm{pH} \\
6.8\end{array}$ & $\begin{array}{l}\mathrm{pH} \\
8.5\end{array}$ & $\begin{array}{c}\mathrm{pH} \\
10\end{array}$ & $\begin{array}{c}\mathrm{pH} \\
12\end{array}$ & $\begin{array}{c}\mathrm{pH} \\
8.5 \\
\text { and } \\
\mathrm{NaCl} \\
4 \%\end{array}$ & $\begin{array}{l}\mathrm{pH} \\
6.8\end{array}$ & $\begin{array}{l}\mathrm{pH} \\
8.5\end{array}$ & $\begin{array}{c}\mathrm{pH} \\
10\end{array}$ & $\begin{array}{l}\mathrm{pH} \\
12\end{array}$ & $\begin{array}{c}\mathrm{pH} \\
8.5 \\
\text { and } \\
\mathrm{NaCl} \\
4 \%\end{array}$ & $\begin{array}{l}\mathrm{pH} \\
6.8\end{array}$ & $\begin{array}{l}\mathrm{pH} \\
8.5\end{array}$ & $\begin{array}{c}\mathrm{pH} \\
10\end{array}$ & $\begin{array}{c}\mathrm{pH} \\
12\end{array}$ & $\begin{array}{c}\mathrm{pH} \\
8.5 \\
\text { and } \\
\mathrm{NaCl} \\
4 \%\end{array}$ \\
\hline $\begin{array}{c}++ \\
\mathrm{NaCl} \\
0 \%\end{array}$ & $\begin{array}{c}++ \\
\mathrm{NaCl} \\
4 \%\end{array}$ & $\begin{array}{c}++ \\
\mathrm{NaCl} \\
8 \%\end{array}$ & $\begin{array}{c}+ \\
\mathrm{NaCl} \\
12 \%\end{array}$ & & $\frac{-}{\mathrm{NaCl}}+\frac{}{0 \%}$ & $\begin{array}{c}++ \\
\mathrm{NaCl} \\
4 \%\end{array}$ & $\begin{array}{c}++ \\
\mathrm{NaCl} \\
8 \%\end{array}$ & $\begin{array}{c}+ \\
\mathrm{NaCl} \\
12 \%\end{array}$ & & $\begin{array}{c}++ \\
\mathrm{NaCl} \\
0 \%\end{array}$ & $\begin{array}{c}++ \\
\mathrm{NaCl} \\
4 \%\end{array}$ & $\begin{array}{c}++ \\
\mathrm{NaCl} \\
8 \%\end{array}$ & $\begin{array}{c}+ \\
\mathrm{NaCl} \\
12 \%\end{array}$ & \\
\hline+ & ++ & + & + & +++ & + & ++ & + & + & +++ & - & ++ & + & + & +++ \\
\hline
\end{tabular}

Legend : $(-)-$ no halos, $(+)-$ small diameter halos, $(++)-$ medium diameter halos, $(+++)$ - large diameter halos

\section{DISCUSSION}

In developing countries, microbial enzyme research is still in its infancy. However, the exploitation of certain discharge sites for the isolation of indigenous microorganisms should be carried out to better assess their microbial diversity and decipher their capacity for producing various enzymes classes. In this context, the present study highlighted the isolation and characterization of three bacteria designated LGMT10, LGMT12, and LGMT8 belonging respectively to the genus Bacillus aquimaris, Pseudomonas aeruginosa, and Bacillus sp. isolated from the effluents of the thermal power plant of Terga, Algeria. Since the first discovery of the novel strain Bacillus aquimaris sp. nov. by Yoon et al. (2003), there are few reports regarding its enzymatic potential. However, the present study 
highlighted the promising potential of new alkali-halotolerant Bacillus aquimaris strain LGMT10 producing three extracellular hydrolases (i.e., protease, amylase, and cellulase) able to resist different ranges of $\mathrm{pH}$ and $\mathrm{NaCl}$ concentrations. In the same context, the majority of studies in the literature have shown the halotolerant nature of Bacillus aquimaris and its ability to grow in $\mathrm{NaCl}$ concentration between $0-12 \%(\mathrm{w} / \mathrm{v})$ (Shivanand and Jayaraman, 2009) in agreement with this study. Furthermore, strain LGMT10 has shown excellent properties to resist $\mathrm{pH}$ and $\mathrm{NaCl}$ for growth and production of the three studied enzymes compared to its counterparts among Bacillus spp and other bacterial genera.

Several bacterial genera that are capable of producing a variety of extracellula enzymes appear to be overly well described in the literature. However, a variety of bacteria has been reported for cellulase production. Trivedi et al. (2011) described the production of an alkalihalotolerant cellulase by Bacillus flexus strain NT. These authors showed that the enzyme, which has a molecular mass of $97 \mathrm{kDa}$ was stable in the $\mathrm{pH}$ range of 9-12 and at a range of $\mathrm{NaCl}$ concentration up to $15 \%$ $(\mathrm{w} / \mathrm{v})$. On the other hand, bacteria such as Klebsiella sp. produce cellulase active at $10{ }^{\circ} \mathrm{C}$ and $\mathrm{pH} 4.5$ (Bhat et al., 2013). Cellulase produced by Marinobacter $\mathrm{sp}$ strain MSI032 was alkalotolerant, active at pH 9 (Shanmughapriya et al., 2010) In contrast to alkaline cellulases, only a few salt-tolerant or halophilic cellulases have been reported (Hirasawa et al., 2006; Voget et al., 2006). Johnson et al (1986) have described a cellulase from halophilic actinomycetes, Actinopolyspora halophila, exhibiting optimal $15 \%$ (w/v) cellulase activity of $\mathrm{NaCl}$. In addition, Simankova et al. (1993) characterized anaerobic eubacteria, Halocella cellulolytica, capable of producing cellulase enzyme at $20 \%(\mathrm{w} / \mathrm{v}) \mathrm{NaCl}$.

There are numerous available studies in the literature on alkaline protease production by Bacillus species. However, Bacillus aquimaris strain VITP4 has been reported to be active in the $\mathrm{pH}$ range of 7-10, with an optimum at $\mathrm{pH} 8$ (Shivanand and Jayaraman 2009, 2011). Currently, there are at least 29 Bacillus species and 17 fungal producers that have been reported to produce alkaline proteases (Veloorvalappil et al., 2013). All the studies published on halotolerant microorganisms have shown that the enzymes from microorganisms which can grow over a concentration range of $\mathrm{NaCl}$ between $0-15 \%(w / v)$ are of great interest for their industrial use, because of their inherent ability to be active and stable both in the presence as well as in the absence of salt (Chittoor $\boldsymbol{e t}$ al. 2016). Moreover, some extracellular halophile proteases have maximum activity at near-neutral $\mathrm{pH}$ that has been reported (Vidyasagar et al., 2006; Norberg and Hofsten, 1969). The Bacillus aquimaris strain VITP4 described by Shivanand and Jayaraman (2011) retained significant activity up to a concentration of $2 \mathrm{M}$ $\mathrm{NaCl}$, in agreement with this study, although it exhibited the highest activity in the absence of $\mathrm{NaCl}$. Even in the presence of $4 \mathrm{M} \mathrm{NaCl}$, the protease retained about $40 \%$ of its activity, indicating the halotolerant behavior of the enzyme. It has been reported that the addition of $\mathrm{NaCl}$ up to a concentration of $5 \%(\mathrm{w} / \mathrm{v})$ had no effect on the proteolytic function of Bacillus cereus. However, enzymatic activity decreased progressively upon further salt addition, and a $60 \%$ reduction in activity was reported when the $\mathrm{NaCl}$ concentration was increased to $10 \%$ (Joshi et al. 2007). There are reports of salt-tolerant protease produced by mesophilic or thermophilic Bacillus spp (Joo and Chang, 2005; Bhushan et al., 1999).

In addition, the study of Anupama and Jayaraman (2011) on the production of extracellular amylase by the halotolerant strain Bacillus aquimaris strain VITP4 from the saltern of Kumta coast showed optimal activity at a pH range of $7.5-9.5$ at $40{ }^{\circ} \mathrm{C}$. Likewise, the partially purified a-amylase of Bacillus aquimaris strain MKSC 6.2 displayed optimum activity at $\mathrm{pH} 6.5$ and $50{ }^{\circ} \mathrm{C}$ (Puspasari et al. 2011). It has been reported that amylases produced by certain halophilic microorganisms have optimal activity at high salinities and could, therefore, be used in many severe industrial processes where the concentrated saline solutions used would otherwise inhibit many enzymatic conversions (Amoozegar et al. 2003; Prakash et al., 2009). It has also been reported that most of the halobacteria enzymes are considerably thermotolerant and remain stable at room temperature for long periods of time (Mohapatra et al., 1998). The halophilic amylases have been characterized from halophilic bacteria such as Chromohalobacter sp. (Prakash et al., 2009), Halobacillus sp. (Amoozegar et al., 2003), Haloarcula hispanica (Hutcheon et al., 2005), Halomonas meridiana (Coronado et al., 2000), and Bacillus dipsosauri (Deutch, 2002). Based on the literature, the main strains that are described in the production of extracellular enzymes among Bacillus spp are presented in Tab 4.

Table 4 Comparative study among some Bacillus strains on the production of extracellular hydrolases

\begin{tabular}{|c|c|c|c|c|}
\hline Bacterial strains & Origin & Producing enzymes & Production proprieties & Study \\
\hline $\begin{array}{l}\text { Bacillus aquimaris strain } \\
\text { LGMT10 }\end{array}$ & $\begin{array}{l}\text { Thermal power plant } \\
\text { effluents, Algeria }\end{array}$ & $\begin{array}{l}\text { Protease } \\
\text { Amylase } \\
\text { Cellulase }\end{array}$ & $\begin{array}{c}\text { pH 6.8-12; NaCl: } 0- \\
12 \% \\
\text { pH } 8.5-12 ; \mathrm{NaCl}: 0- \\
12 \% \\
\text { pH 6.8-12; NaCl: } 4- \\
12 \%\end{array}$ & Our study \\
\hline $\begin{array}{l}\text { Bacillus aquimaris strain } \\
\text { VITP4 }\end{array}$ & Kumta coast & $\begin{array}{l}\text { Protease } \\
\text { Amylase }\end{array}$ & $\begin{array}{c}\text { pH 7-10; } \mathrm{NaCl}: 0-2 \mathrm{M} \\
\text { pH } 7.5-9.5\end{array}$ & $\begin{array}{c}\text { (Shivanand and } \\
\text { Jayaraman, 2009, 2011) } \\
(\text { Shivanand and } \\
\text { Jayaraman, 2011) }\end{array}$ \\
\hline $\begin{array}{l}\text { Bacillus subtilis (ATCC } \\
6633 \text { ) }\end{array}$ & nd & Amylase & pH 6-11 & (Maity et al., 2015) \\
\hline Bacillus cereus $\mathrm{RSA} 1$ & Soil samples & protease & $\mathrm{pH} 5-10$ & (Sharma et al., 2020) \\
\hline $\begin{array}{l}\text { Bacillus licheniformis } \\
\text { HI-08 }\end{array}$ & $\begin{array}{l}\text { The gut of building } \\
\text { infesting termite } \\
\text { Heterotermes indicola }\end{array}$ & Cellulase & pH 3-10 & (Afzal et al., 2019) \\
\hline Bacillus flexus NT & $\begin{array}{l}\text { Green seaweed Ulva } \\
\text { lactuca }\end{array}$ & Cellulase & $\mathrm{pH} 8-12 ; \mathrm{NaCl}: 0-21 \%$ & (Trivedi et al., 2011) \\
\hline Bacillus subtilis B22 & Homemade kimchi & Protease & $\mathrm{pH} 7-10$ & (Elumalai et al., 2020) \\
\hline
\end{tabular}

Legend: $n d$ - not determined

\section{CONCLUSION}

The microbial diversity of the Terga thermal power plant's effluents was investigated in this study, which revealed an intriguing enzymatic potential as well as the identification of a novel alkali-halotolerant bacterium, Bacillus aquimaris strain LGMT10 capable to produce three extracellular hydrolases (i.e., amylase, cellulase, and protease) in the $\mathrm{pH}$ range of $6.8-12$, and at $\mathrm{NaCl}$ concentrations between $0-12 \%(\mathrm{w} / \mathrm{v})$ at $30{ }^{\circ} \mathrm{C}$. These findings bode well for better understanding the capabilities of novel microorganisms from this new site, in Algeria. In addition, the measurement of the enzymatic activities of purified enzymes and their biochemical characterization will be performed using more accurate techniques, such as sodium dodecyl sulphate-polyacrylamide ge electrophoresis (SDS-PAGE) and zymograhy, in order to provide the data necessary for their catalyzing capacities, for a possible affiliation of each enzyme towards the corresponding industry.

Acknowledgements : The authors are grateful for the help they received from England's Newcastle Laboratory in molecularly identifying bacteria strains. We would like to express our gratitude to Bekkaye Ikram Imene of Oran's LBMB laboratory for her assistance with the statistical analyses section.

\section{REFERENCES}

Abd Samad, N. S., Amid, A., Jimat, D. N., \& Shukor, N. A. A. (2017). Isolation and identification of halophilic bacteria producing halotolerant protease. Sci. Herit. J., 1, 07-09. https://doi.org/10.26480/gws.01.2017.07.09

Afzal, M., Qureshi, M. Z., Khan, S., Khan, M. I., Ikram, H., Ashraf, A., \& Qureshi, N. A. (2019). Production, purification and optimization of cellulase by Bacillus licheniformis HI-08 isolated from the hindgut of wood-feeding termite. Int J. Agric. Biol. 21(1), 125-134. https://doi.org/10.17957/IJAB/15.0872

Amoozegar, M. A., Malekzadeh, F., \& Malik, K. A. (2003). Production of amylase by newly isolated moderate halophile, Halobacillus sp. strain MA-2. J. Microbial. Meth., 52(3), 353-359. https://doi.org/10.1016/S0167-7012(02)00191-4

Anbu, P. (2016). Enhanced production and organic solvent stability of a protease from Brevibacillus laterosporus strain PAP04. Brazilian Journal of Medical and Biological Research, 49(4). https://doi.org/10.1590/1414-431X20165178

Anbu, P., Gopinath, S. C., Cihan, A. C., \& Chaulagain, B. P. (2013). Microbial enzymes and their applications in industries and medicine. http://dx.doi.org/10.1155/2013/204014

Anupama, A., \& Jayaraman, G. (2011). Detergent stable, halotolerant $\alpha$-amylase from Bacillus aquimaris vitp4 exhibits reversible unfolding. IJABPT, 2, 366-76. 
Anwar, A., \& Saleemuddin, M. (1998). Alkaline proteases: a review. Bioresource technology, 64(3), 175-183. https://doi.org/10.1016/S0960-8524(97)00182-X

Ardakani, M. R., Poshtkouhian, A., Amoozegar, M. A., \& Zolgharnein, H. (2012). Isolation of moderately halophilic pseudoalteromonas producing extracellular hydrolytic enzymes from Persian Gulf. Indian journal of microbiology, 52(1), 94 98. https://doi.org/10.1007/s12088-011-0243-x

Bhat, A., Riyaz-Ul-Hassan, S., Ahmad, N., Srivastava, N., \& Johri, S. (2013) Isolation of cold-active, acidic endocellulase from Ladakh soil by functiona metagenomics. Extremophiles, 17(2), 229-239. https://doi.org/10.1007/s00792012-0510-8

Bhushan, B., Beg, Q. K., \& Hoondal, G. S. (1999). Partial purification and characterization of a thermostable alkaline protease of an alkalophilic Bacillus sp. NG-27. Indian Journal of Microbiology, 39(3), 185-188.

Chittoor, J. T., Balaji, L., \& Jayaraman, G. (2016). Optimization of parameters that affect the activity of the alkaline protease from halotolerant bacterium, Bacillus acquimaris VITP4, by the application of response surface methodology and evaluation of the storage stability of the enzyme. Iranian Journal of Biotechnology, 14(1), 23. https://doi.org/10.15171/ijb.1269

Choi, J. M., Han, S. S., \& Kim, H. S. (2015). Industrial applications of enzyme biocatalysis: Current status and future aspects. Biotechnology advances, 33(7), 1443-1454. https://doi.org/10.1016/j.biotechadv.2015.02.014

Coronado, M. J., Vargas, C., Hofemeister, J., Ventosa, A., \& Nieto, J. J. (2000) Production and biochemical characterization of an $\alpha$-amylase from the moderate halophile Halomonas meridiana. FEMS microbiology letters, 183(1), 67-71. https://doi.org/10.1111/j.1574-6968.2000.tb08935.x

Deutch, C. E. (2002). Characterization of a salt-tolerant extracellular a-amylase from Bacillus dipsosauri. Letters in applied microbiology, 35(1), 78-84. https://doi.org/10.1046/j.1472-765X.2002.01142.x

Dutka-Malen, S., Evers, S., \& Courvalin, P. (1995). Detection of glycopeptide resistance genotypes and identification to the species level of clinically relevant enterococci by PCR. Journal of clinical microbiology, 33(1), 24-27.

Koraichi, I., \& Harchli, E. Contribution À La Caractérisation Microbiologique Et Enzymatique D'un Site Extrême: Les Tanneries Traditionnelles De Fès. International Journal of Engineering and Science 5: 16-24

Elumalai, P., Lim, J. M., Park, Y. J., Cho, M., Shea, P. J., \& Oh, B. T. (2020) Agricultural waste materials enhance protease production by Bacillus subtilis B22 in submerged fermentation under blue light-emitting diodes. Bioprocess and Biosystems Engineering, 1-10. https://doi.org/10.1007/s00449-019-02277-5

Fiedurek, J., \& Gromada, A. (2000). Production of catalase and glucose oxidase by Aspergillus niger using unconventional oxygenation of culture. Journal of applied microbiology,89(1), 85-89. https://doi.org/10.1046/j.13652672.2000.01085.x

Gopinath, S. C., Anbu, P., \& Hilda, A. (2005). Extracellular enzymatic activity profiles in fungi isolated from oil-rich environments. Mycoscience, 46(2), 119 126. https://doi.org/10.1007/s10267-004-0221-9

Gopinath, S. C., Anbu, P., Lakshmipriya, T., \& Hilda, A. (2013). Strategies to characterize fungal lipases for applications in medicine and dairy industry. BioMed research international, 2013. https://doi.org/10.1155/2013/154549

Hasan, F., Shah, A. A., \& Hameed, A. (2009). Methods for detection and characterization of lipases: a comprehensive review. Biotechnology advances, 27(6), 782-798. https://doi.org/10.1016/j .biotechadv.2009.06.001

Hirasawa, K., Uchimura, K., Kashiwa, M., Grant, W. D., Ito, S., Kobayashi, T., \& Horikoshi, K. (2006). Salt-activated endoglucanase of a strain of alkaliphilic Bacillus agaradhaerens. Antonie Van Leeuwenhoek, 89(2), 211-219. https://doi.org/10.1007/s10482-005-9023-0

Hutcheon, G. W., Vasisht, N., \& Bolhuis, A. (2005). Characterisation of a highly stable $\alpha$-amylase from the halophilic archaeon Haloarcula hispanica. Extremophiles, 9(6), 487-495. https://doi.org/10.1007/s00792-0050471-2

Johnson, K. G., Lanthier, P. H., \& Gochnauer, M. B. (1986). Studies of two strains of Actinopolyspora halophila, an extremely halophilic actinomycete. Archives of microbiology, 143(4), 370-378. https://doi.org/10.1007/BF00412805

Joo, H. S., \& Chang, C. S. (2005). Oxidant and SDS-stable alkaline protease from a halo-tolerant Bacillus clausii I-52: enhanced production and simple purification. Journal of applied microbiology,98(2), 491-497. https://doi.org/10.1111/j.1365-2672.2004.02464.X

Joshi, G. K., Kumar, S., \& Sharma, V. (2007). Production of moderately halotolerant, SDS stable alkaline protease from Bacillus cereus MTCC 6840 isolated from lake Nainital, Uttaranchal state, India. Brazilian Journal of Microbiology, 38(4), 773-779. $\quad$ https://doi.org/10.1590/S151783822007000400034

Kumar, S., Stecher, G., \& Tamura, K. (2016). MEGA7: molecular evolutionary genetics analysis version 7.0 for bigger datasets. Molecular biology and evolution, 33(7), 1870-1874. https://doi.org/10.1093/molbev/msw054

Li, S., Yang, X., Yang, S., Zhu, M., \& Wang, X. (2012). Technology prospecting on enzymes: application, marketing and engineering. Computational and structural biotechnology journal, 2(3),

e201209017.

https://doi.org/10.5936/csbj.201209017
Litchfield, C. D. (2002). Halophiles. Journal of industrial microbiology \& biotechnology, 28(1), 21-22. https://doi:10.1038/sj/jim/7000202

Maity, S., Mallik, S., Basuthakur, R., \& Gupta, S. (2015). Optimization of solid state fermentation conditions and characterization of thermostable alpha amylase from Bacillus subtilis (ATCC 6633). Journal of Bioprocessing \& Biotechniques, 5(4), 1. https:// doi:10.4172/2155-9821.1000218

Mohapatra, B. R., Banerjee, U. C., \& Bapuji, M. (1998). Characterization of a fungal amylase from Mucor sp. associated with the marine sponge Spirastrella sp. Journal of Biotechnology, 60(1-2), 113-117. https://doi.org/10.1016/S01681656(97)00197-1

Nandhini, B., \& Josephine, R. M. (2013). A study on bacterial and fungal diversity in potted soil. International Journal of Current Microbiology and Applied Sciences, 2(2), 1-5.

Norberg, P., \& Hofsten, B. V. (1969). Proteolytic enzymes from extremely halophilic bacteria. Microbiology, 55(2), 251-256. https://doi.org/10.1099/00221287-55-2-251

Novy, V., Longus, K., \& Nidetzky, B. (2015). From wheat straw to bioethanol: integrative analysis of a separate hydrolysis and co-fermentation process with implemented enzyme production. Biotechnology for biofuels, 8(1), 46 https://doi.org/10.1186/s13068-015-0232-0

Prakash, B., Vidyasagar, M., Madhukumar, M. S., Muralikrishna, G., \& Sreeramulu, K. (2009). Production, purification, and characterization of two extremely halotolerant, thermostable, and alkali-stable $\alpha$-amylases from Chromohalobacter sp. TVSP 101. Process Biochemistry, 44(2), 210-215. https://doi.org/10.1016/j.procbio.2008.10.013

Puspasari, F., Nurachman, Z., Noer, A. S., Radjasa, O. K., van der Maarel, M. J., \& Natalia, D. (2011). Characteristics of raw starch degrading $\alpha$-amylase from Bacillus aquimaris MKSC 6.2 associated with soft coral Sinularia sp. StarchStärke, 63(8), 461-467. https://doi.org/10.1002/star.201000127

Sardessai, Y. N., \& Bhosle, S. (2004). Industrial potential of organic solvent $\begin{array}{llr}\text { tolerant } & \text { bacteria. Biotechnology } & \text { Progress, 20(3), }\end{array}$ https://doi.org/10.1021/bp0200595

Sato, T., Hu, J. P., Ohki, K., Yamaura, M., Washio, J., Matsuyama, J., \& Takahashi, N. (2003). Identification of mutans streptococci by restriction fragment length polymorphism analysis of polymerase chain reaction-amplified $16 \mathrm{~S}$ ribosomal RNA genes. Oral microbiology and immunology, 18(5), 323-326 https://doi.org/10.1034/j.1399-302X.2003.00095.x

Shanmughapriya, S., Kiran, G. S., Selvin, J., Thomas, T. A., \& Rani, C. (2010) Optimization, purification, and characterization of extracellular mesophilic alkaline cellulase from sponge-associated Marinobacter sp. MSI032. Applied biochemistry and biotechnology, 162(3), 625-640. https://doi.org/10.1007/s12010$\underline{009-8747-0}$

Sharma, C., Salem, G. E. M., Sharma, N., Gautam, P., \& Singh, R. (2020) Thrombolytic Potential of Novel Thiol-Dependent Fibrinolytic Protease from Bacillus cereus RSA1. Biomolecules, 10(1)

https://doi.org/10.3390/biom10010003

Sharma, N., Singh, A., Bhatia, S., \& Batra, N. (2019). Marine Microbes in Bioremediation: Current Status and Future Trends. In Microbes and Enzymes in Soil Health and Bioremediation (pp. 133-148). Springer, Singapore https://doi.org/10.1007/978-981-13-9117-0_6

Shivanand, P., \& Jayaraman, G. (2009). Production of extracellular protease from halotolerant bacterium, Bacillus aquimaris strain VITP4 isolated from Kumta coast. Process Biochemistry, 44(10) 1088-1094. https://doi.org/10.1016/j.procbio.2009.05.010

Shivanand, P., \& Jayaraman, G. (2011). Isolation and characterization of a metal ion-dependent alkaline protease from a halotolerant Bacillus aquimaris VITP4 Indian Journal of Biochemistry and Biophysics 48, 95-100.

Shukla, P. (2019). Synthetic Biology Perspectives of Microbial Enzymes and Their Innovative Applications. Indian journal of microbiology, 1-9. https://doi.org/10.1007/s12088-019-00819-9

Simankova, M. V., Chernych, N. A., Osipov, G. A., \& Zavarzin, G. A. (1993) Halocella cellulolytica gen. nov., sp. nov., a new obligately anaerobic, halophilic, cellulolytic bacterium. Systematic and applied microbiology, 16(3), 385-389. https://doi.org/10.1016/S0723-2020(11)80270-5

Souii, A., Guesmi, A., Ouertani, R., Cherif, H., Chouchane, H., Cherif, A., \& Neifar, M. (2020). Carboxymethyl cellulase production by extremotoleran bacteria in low-cost media and application in enzymatic saccharification of Stevia biomass. Waste and Biomass Valorization, 11(5), 2111-2122. https://doi.org/10.1007/s12649-018-0496-2

Trivedi, N., Gupta, V., Kumar, M., Kumari, P., Reddy, C. R. K., \& Jha, B. (2011) An alkali-halotolerant cellulase from Bacillus flexus isolated from green seaweed Ulva lactuca. Carbohydrate polymers, 83(2), 891-897. https://doi.org/10.1016/j.carbpol.2010.08.069

Veloorvalappil, N. J., Robinson, B. S., Selvanesan, P., Sasidharan, S., Kizhakkepawothail, N. U., Sreedharan, S., ... \& Sailas, B. (2013). Versatility of microbial proteases. Advances in enzyme research, 2013. https://doi.org/10.4236/aer.2013.13005

Venkateshwaran, G., Somashekar, D., Prakash, M. H., Agrawal, R., Basappa, S C., \& Joseph, R. (1999). Production and utilization of catalase using 
Saccharomyces

cerevisiae. Process

Biochemistry, 34(2),

$187-191$

https://doi.org/10.1016/S0032-9592(98)00087-9

Vidyasagar, M., Prakash, S., Litchfield, C., \& Sreeramulu, K. (2006). Purification and characterization of a thermostable, haloalkaliphilic extracellular serine protease from the extreme halophilic archaeon Halogeometricum borinquense strain TSS101. Archaea, 2(1), 51-57. https://doi:10.1155/2006/430763

Voget, S., Steele, H. L., \& Streit, W. R. (2006). Characterization of a metagenomederived halotolerant cellulase. Journal of biotechnology,126(1), 26-36. https://doi.org/10.1016/j.jbiotec.2006.02.011

Yoon, J. H., Kim, I. G., Kang, K. H., Oh, T. K., \& Park, Y. H. (2003). Bacillus marisflavi sp. nov. and Bacillus aquimaris sp. nov., isolated from seawater of a tidal flat of the Yellow Sea in Korea. Journal of Medical Microbiology, 53(5), 1297-1303. https://doi.org/10.1099/ijs.0.02365-0

Zhang, C., \& Kim, S. K. (2010). Research and application of marine microbial enzymes: $\quad$ status and prospects. Marine drugs, 8(6), 1920-1934. https://doi.org/10.3390/md8061920 